\title{
Éditorial : Protection des Plantes dans les Agroécosystèmes Méditerranéens
}

\author{
Serge Kreiter ${ }^{(1)}$, Patrice A. Marchand ${ }^{(2)}$, Alice Baudet ${ }^{(3)}$ \\ (1) Montpellier SupAgro, UMR CBGP (SupAgro/CIRAD/INRA/IRD), 755 avenue du Campus Agropolis, CS 30016, 34988 \\ Montferrier-sur-Lez cedex, France. E-mail : serge.kreiter@supagro.fr \\ (2) ITAB, Institut Technique de l'Agriculture Biologique, Inputs Dept. Paris (France), 149 rue de Bercy, 75595 Paris cedex \\ 12, France. E-mail : patrice.marchand@itab.asso.fr \\ (3) Végéphyl, 42 rue Raymond Jaclard, 94140 Alfortville, France. E-mail : alice.baudet@ vegephyl.fr
}

Cet article est distribué suivant les termes et les conditions de la licence CC-BY (http://creativecommons.org/licenses/by/4.0/ deed.fr)

La multi-dimensionnalité de la question agricole et rurale en Méditerranée milite pour que soit enclenchée une mobilisation euro-méditerranéenne de grande ampleur sur ce sujet. Car l'agriculture se situe au cœur de l'identité méditerranéenne et s'affiche comme un déterminant essentiel pour les économies et les sociétés de cette grande Région. Le développement de la recherche autour du bassin méditerranéen ne peut pas ignorer la complexité des processus impliqués dans les changements globaux, notamment ceux en relation avec les modifications climatiques et les activités anthropiques. Il ne peut pas se résumer uniquement à des approches purement agronomiques et doit envisager un cadre à la fois plus systémique et plus participatif. Étant donné la diversité des éco-anthroposystèmes méditerranéens et le nombre de facteurs et de processus qui affaiblissent cette diversité, les pays méditerranéens représentent un espace exceptionnel pour développer ces approches de recherche. La gestion de la Protection des Plantes dans les Agroécosystèmes Méditerranéens s'intéresse entre autres aspects à la fois aux invasions biologiques (ravageurs, maladies et adventices), aux Organismes Nuisibles (ON) réglementés et émergents, au rôle des agences nationales et internationales (Robin \& Marchand, 2018), à la lutte biologique et à la Protection Intégrée des Cultures (PIC) (Kreiter, 2018) et à l'éducation et formation en santé des plantes.

Cette édition spéciale sur la Protection des Plantes dans les Agroécosystèmes Méditerranéens regroupe des publications correspondant à une approche système (Djian-Caporalino et al., 2019), à la protection intégrée des cultures (Charon et al., 2019), aux rôles des agences (Baldissera et al., 2019 ; Picard et al., 2019), aux invasions biologiques (Radonjic et al., 2019).

\section{Plant Protection in Mediterranean Agroecosystems}

The multi-dimensionality of the agricultural and rural question in the Mediterranean requires a Euro-Mediterranean mobilization on this subject. Agriculture is at the heart of the Mediterranean identity and represents an essential determinant for the economies and companies of the area. Research being developed around the Mediterranean basin cannot disregard the complexity of the processes involved in global changes, especially in relation to climate and to anthropogenic activities. This research can no longer be confined to agronomic approaches, and must contemplate a more systemic framework. Given the diversity of the Mediterranean eco-anthroposystems and the diversity of weakening mechanisms imposed upon them, Mediterranean countries are exceptionally well-suited to developing these research approaches. Management of Plant Protection in Mediterranean Agroecosystems oversees the following: monitoring of biological invasions (pests, diseases and weeds); regulation of emerging harmful organisms (NMOs); the role of national and international agencies (Robin \& Marchand, 2018); biological control, integrated pest management (IPM) (Kreiter, 2018), and plant health education and training.

This special edition of the Plant Protection in Mediterranean Agroecosystems includes publications corresponding to the system approach (Djian-Caporalino et al., 2019), the integrated protection of culture (Charon et al., 2019), the role of agencies (Baldissera et al., 2019; Picard et al., 2019) and biological invasions (Radonjic et al., 2019).

\section{Bibliography}

Charon M., Robin D. \& Marchand P.A., 2019. The major interest for crop protection of agrochemical substances without maximum residue limit (MRL). Biotechnol. Agron. Soc. Environ., 23(1), 22-29. 
Djian-Caporalino C. et al., 2019. Conception et évaluation de systèmes de culture maraîchers méditerranéens innovants pour gérer les nématodes à galles. Biotechnol. Agron. Soc. Environ., 23(1), 7-21.

Giovani B. et al., 2019. From transnational research collaboration to regional standards. Biotechnol. Agron. Soc. Environ., 23(1), 30-35.

Kreiter S., 2018. Pest management in organic grape production. Chapter 7. 173-217. In: Vancante V. \& Kreiter S., eds. Handbook of pest management in organic farming. CABI.

Picard C. et al., 2019. Recommended Regulated Non-Quarantine Pests: towards a wider and better application of the international concept in the EPPO region. Biotechnol. Agron. Soc. Environ., 23(1), 36-45.

Radonjić S., Hrnčić S. \& Perović T., 2019. Overview of fruit flies important for fruit production on the Montenegro seacoast. Biotechnol. Agron. Soc. Environ., 23(1), 46-56.

Robin D. \& Marchand P.A., 2018. Biocontrol active substances: evolution since the entry in vigour of Reg. 1107/2009. Pest Manage. Sci., DOI: org/10.1002/ps.5199 